\title{
On Pakistan's Independence Day: Egyptian-Pakistani Distinguished Relations
}

\author{
H.E. Mr. Mushtaq Ali Shah \\ Ambassador of Pakistan in Cairo
}

\section{The Independence Day:}

In the checkered history of the Muslims of the Subcontinent two dates are extremely important for their lasting impact on the course of political events in this part of the world. These are March 23, 1940 and August 14, 1947.

March 23, 1940 signaled the launching of mass movement by the Muslims of South Asia and also the beginning of an arduous struggle, which they started under the unparallel leadership of Quaid-e-Azam Muhammad Ali Jinnah. The clarion call given by him on that date motivated and energized the Muslims to work relentlessly for the achievement of separate homeland.

On August 14, 1947 the Muslims of the Subcontinent achieved their independence to become the masters of their own destiny. It has its roots into the remote past. Its establishment was the culmination of the struggle of the Muslims of South Asia. The first proponents of independent Muslim nation began to appear during the time of British India. Among the first of these proponents was the poet/philosopher Allama Iqbal who felt that a separate nation for Muslims was essential in a Hindu dominated Sub-continent.

The cause found a leader in Mohammad Ali Jinnah. The Quaid-e-Azam had once said that Pakistan was established on the day the first Muslim came to India. It indicates that though we achieved independence on August 14, 1947 but in fact the dream was realized after a constant struggle for countries. In this connection the determined efforts and selfless services of renowned Muslims Saints and religious scholars like Shah Wali-Ullah, Khawaja Mueeen-udDin Chishti, Mujaddid Alf Sani, Khawaja Nizam-ud-Din Aoulia,, Syed Ismail Shaheed, Aurangzeb Alamgir, Tipu Sultan Shaheed and thousand of others sincere Muslims whose names some how could not be recorded in history, amply paved the way for the creation of our homeland.

These were the people who realizing the acuteness of the problem of diminishing Muslim Identity laid the foundation of Islamic renaissance and became a source of inspiration for almost all the social and religious reform movements of nineteenth and twentieth centuries. The luminaries stuck to the right 
path and upheld the banner of dissemination of divine teaching of the universal faith of Islam, truth, justice, peace and piety, under very odd circumstances.

The Independence Day signifies remembering of contributions and sacrifices of our leaders, elders towards establishment of Pakistan. We had resolved to achieve a state where we may flourish politically and shape our religious and cultural life and where all the citizens in pursuance of golden doctrines of Islam would be entitled to enjoy equal status in every field of life irrespective of their creed, race \& religion. And it is exactly what is called the ideology of Pakistan, which was emphatically explained by Quaid-i-Azam time and again through his speeches and statements during the course of Pakistan movement. The demand for Pakistan became popular during the Second World War. Every section of the Muslim community-men, women, students, ulema and businessmen were organized under the banner of All-India Muslim League. The Muslim community responded to the call for Pakistan in an unprecedented way.

The word Pakistan entails Land of Pure where people could lead their lives according to their faith and belief. It is a day of solemn pledge by every citizen of this land to work for its development keeping aside his conflicts, sectarian beliefs and thoughts. It is a day for every Pakistani to remember the sacrifices of past and divert all out efforts to make Pakistan a leading country in the community of nations.

\section{0 years of independence:}

Today, the people of Pakistan celebrate 70 years of independence, which was achieved as the fruit of Freedom Movement, launched by Muslims of the Subcontinent under valiant leadership of their great Qaid, Muhammad Ali Jinnah. Unflinching resolve and sustained struggle of the disenfranchised people quickly culminated in creation of a sovereign State. The new State embraced the principles of faith, equality, freedom, justice for its citizens and support to the right of self determination of subjugated people around the world.

Seven decades of passion and devotion have solidified the nation that remains ever ready to defy adversity and overcome challenges on economic and security fronts. Pragmatic policies pursued by governments over the past seventy years and perseverance of the people have transformed the essentially agrarian into a vibrant economy, with a broad industrial base, fast growing services sector and highyielding stock exchange. The country is self sufficient in food and exporter of cotton, wheat, riceand fresh fruits.

Other traditional exports include textiles, cement, surgical equipment, engineering goods and other value added products. Pakistan has also been success- 
ful in indigenizing defence production and become an exporter of defence products, including the reputable JF-17 Thunder aircraft and other military hardware.

Strategic location at the confluence of South, Central and West Asia, makes Pakistan a hub of trade and energy corridors in the region. Means of communications, including road network, railways and deep sea ports are now being expanded and upgraded to cater to the growing volumes of regional trade and ensure energy supplies to the fast growing economy. It is in this spirit that Pakistan has partnered with China to develop the China-Pakistan Economic Corridor (CPEC) that aims at facilitating regional and global trade, through the historical silk route that passes over Karakorum range and connects with sea lanes at the deep seaport of Gwadar.

As a result of dynamic policies pursued by the present government, which are focused on liberalization and de-regulation, the Pakistan Stock Exchange has this year joined the rank of MSCI Emerging Markets while the country prepares to become Asia's trade, energy and transport corridor. The strategic advantage of proximity to the energy rich Central and West Asiamakes Pakistan a natural corridor for trade and energy supplies. Pakistan itself also possesses a large pool of qualified and trained manpower comprising engineers, bankers, lawyers and other professionals with substantial experience.

Although the new State came into being only seventy years ago, the history of the people is embedded with the Indus Valley civilization, which has evolved over the past six thousand years on the mosaic of meadows, plateaus, valleys, wetlands, glaciers and mountains, structuring from Siachen glaciers in the foothills of the Himalayas down to the Arabian Ocean.

The sixth most populous nation now plays an active role in the UN agencies as also regional organizations, like; the Organization of Islamic Countries (OIC), the South Asian Association for Regional Cooperation (SAARC) and the Economic Cooperation Organization (ECO). Despite facing security challenges at home Pakistan is proud to be the largest contributor of troops to UN peacekeeping missions, which reflect our commitment to promote global peace and stability.

\section{The relations between Pakistan's and Egypt :}

Around 5000 years ago, two great civilizations flourished, one on the banks of the Nile and the other in the Indus valley.

Like Egypt, Pakistan enjoys a unique geo-strategic position. It is a bridge between East, West and Central Asia.

Pakistan and Egypt are bound together by inseparable bonds of faith, cul- 
ture and friendship based on shared perceptions. Pakistan and Egypt have a complete understanding on almost all issues of regional and global significance.

Pakistan is keen to further develop its close brotherly ties with Egypt in all fields. Both the countries have much in common to share by way of their indigenous resources, technical skills and industrial potentials. There is much scope to expand trade and commercial ties and further boost cooperation in the fields of education, culture and communication media.

The Government of Pakistan remains actively engaged in actively identifying, with input from the private sector the potential areas for Pak-Egypt trade and investment. These areas include textiles, packaging and chemical industries. There are clear complementaries in certain areas between Pakistan and Egypt.

Pakistan's relations with Egypt are based on similarity of perception on major regional and global issues, shared goals of promoting peace, security and harmony and the bonds of fraternity and cultural affinities that so happily exist between our two countries. In the recent past, we have witnessed perceptible warmth in bilateral relations with frequent contacts at political level and the exchange of ministerial level visits. We were able to hold the seventh round of political consultations in Cairo last year, after a gap of five years. We are now working to organizethe next session of Joint Ministerial Commission, which has not convened since 2010 .

The volume of bilateral trade has remained steady over the past few years. However, economic fundamentals of our two countries are complementary to each other in many fields. Businesspeople of our two countries have been participating in trade exhibitions to take advantage of the opportunities for cooperation.

The scope and potential for growth in trade and investments give us the confidence that our efforts and activities will help boost bilateral trade and economic cooperation in the years ahead. 